\title{
Experience Report: Dengue Control Workshops to Promote Intersectoral Responsibility and Popular Participation
}

Danielle de Norões Mota1, Maria Iracema Mariano de Amorim², Antônio Soares da Silva², Diones Gomes da Silva², Duciele Araújo Pinheiro Bione1, Keila Formiga de Castro ${ }^{2,4}$, Maria Darcylene de Souza Feitosa1, Sheyla Martins Alves ${ }^{1}$, Mirna Neyara Alexandre de Sá Barreto Marinho1, Fabíola de Lima Gonçalves ${ }^{3}$, Hermes Melo Teixeira Batista ${ }^{4}$, André Luís Sant'Anna5, Dayanne Rakelly de Oliveira1, Edilma Gomes Rocha Cavalcante ${ }^{1}$

\section{Abstract}

Introduction: Dengue is considered a disease of great epidemiological impact, that occurs mainly in tropical and subtropical countries. In Brazil, it has shown an increase in all regions of the country, with the highest incidence in the Southeast and Midwest regions.

Objective: To describe the practical experience of carrying out dengue control workshops to promote intersectoral responsibility and popular participation.

Methods: Descriptive study, as a reporting experience, developed by surveillance in Health Care in the Basic Attention for the Dengue Control, from Crato, in state of Ceará, Brazil. It was carried out from April to November 2014, in areas with higher building infestation rate. During this period, many actions were held, such as: situational diagnosis of the most affected areas with dengue in the municipality; meetings and workshops, preparing and implementing a local action plan, which included thirteen teams of health family, with community members and other services.

Results: Five workshops were held with community and intersectoral participation. Actions with active focus searching were carried out on various community contexts, by choosing the D-Day, doing the spot spraying; health communication through posters and sound
1 Membro do grupo de Pesquisa em Saúde Coletiva da Universidade Regional do Cariri -GRUPESC. Crato, Ceará, Brazil.

2 Secretaria de Saúde do município do Crato.Ceará, Brasil.

3 Docente da Universidade de Fortaleza (Unifor). Doutoranda em Saúde Coletiva UECE.

4 Laboratório de Delineamento de Estudos e Escrita Científica. Faculdade de Medicina do ABC, Santo André, São Paulo, Brazil.

5 Hospital Regional do Cariri, Juazeiro do Norte, Ceará, Brazil.

Contact information:

Hermes Melo Teixeira Batista

$\equiv$ hermesmelo@oi.com.br 
cars. Besides, technical qualification of health professionals regarding the usage of the flowchart for suspects and notifications cases. The construction of the local actions plan and its execution reduced the number of cases and the infestation data.

Conclusion: This experience has shown that dengue combat actions became effecient in so far as it is able to develop joint actions, seeking inter-sectoral and community partnerships. Local initiative on the control of dengue is really important in our country, since it makes accessible this kind of attention and demonstrate its effectiveness to the society.

\section{Keywords}

Dengue; Intersectoral action; Community participation; Vector control; Primary care.

\section{Introducion}

Dengue is a great epidemiological health problem in the world. In Brazil, in 2015, it has shown an increase in all regions of the country, with the highest incidence in the Southeast and Midwest [1]. However, the brazilian Northeast region concentrates most of the municipalities at risk of epidemic of dengue [2].

Regarding the state of Ceará, cases of dengue have been notified since 1986. It is shown that dengue was an endemic form expression for 29 years in that state. In the comparative analysis between the years 2014 and 2015, until the epidemiology week 34 , there was observed an increase of $166 \%$ of the reported cases in Ceará, considering the same period [3].

The growth morbidity and mortality are signs of insufficient vector control. Disease control is effectivelly possible when we consider the environment and the way of life within a specific geographic context, emphasizing the climate changes, disorganized urbanization and, above all, the failure of the control policy of the disease [4]. In fact, the epidemiological aspects of the disease promote concerns that requires involvement of human resources as technicians, researchers and society in general, as well as financial investments [5].
In face of the complexity to avoid dengue epidemics that goes beyond the limits of the health sector, the challenge consists on articulate "a set of policy measures, technical and social actions" [5].

In this sense, it encounters with the need for integrated and participative management, which adds the potential to contribute seeking solutions to the complex context, that favors the transmission of the mosquito. In this perspective, interventions must go beyond vector biological control, including participatory promotion in communities, engaging in conversions and more effective actions to control dengue $[5,6]$.

The proposal of community participation is one of the ten components of the National Program for Dengue Control (PNDCD), consistent with the local specificities. Thus, other strategies to be implemented in the municipalities must turn to the determinants of health that require interdisciplinary approaches, public policy and health $[5,7]$.

Thus, to achieve and respond to the demands and health needs, it is necessary the development of the health plan. This participatory process is extremely necessary to the municipalities with high incidence of dengue and involves different agents and services for formulation and execution of the actions [8]. 
The objective of this proposal was to describe the practical experience of conducting dengue control workshops to institute shared responsibility between staff, community members and various services of the municipality.

\section{Methods}

Descriptive study, as a reporting experience, experienced by surveillance staff in Health: epidemiological, health, endemic and social mobilization in the execution of interventions and actions to control dengue in primary health care, from April to November 2014 in the municipality of Crato, state of Ceará, in Brazil.

This municipality organizes its primary care through the Family Health Strategy (ESF/FHS), which is responsible for rearrange the health services. It has twenty-nine Basic Health Units and count on forty ESF, distributed between urban and rural areas.

The experience reported here originated from the monitoring of dengue cases in the municipality. Initially it was made a situational analysis from the collection of secondary data and, then, the following steps and actions were followed:

A) Survey the number of dengue cases, and the intersection of these with the infestation Building Index (PII) to identify the most affected areas by the number of reported cases in ESF.

B) Promotion of intersectoral meetings with coordinators of Epidemiology, Primary Care, Health Surveillance, Environment, Public Cleaning, Endemic Diseases, Social Mobilization for planning the local action.

C) Achievement of workshops at identified locations with the presence of various social agents, to elaborate the action plan based on epidemiological data.

D) Implementation of the Action Plan by all the agents involved besides partnerships and training of health teams.
The intervention consists on build a shared work process with the Family Health Team, the participation of other services and the community to develop the activities of the action plan against dengue in the municipality. The results are shown in topic separately, for better understanding of what has been done in each step and corresponding actions. The analysis of the results was performed from the relevant literature on the subject.

\section{Results and discussion}

\section{Situational diagnosis of dengue in the municipality}

To contribute effectively to the control of dengue, it was considered consideration the territory and epidemiological data of the disease in the municipality. Thus, initially, the Epidemiological Surveillance has performed the previous survey about the number of dengue cases and made comparative analysis between the years 2014 and 2013. For this, it is considered the epidemiological weeks 17 to 24 . It was found that in 2014, there was an increase on the number of notifications (171) with 111 confirmed cases, when compared to the year 2013, where 136 cases were reported, 57 of them were confirmed. This increase was also demonstrated in the epidemiological week 36, in which the municipality has already showed 39 confirmed cases of dengue, while in 2013 there were only six confirmed ones on line by Notifications Diseases Information System (SINAN) in 2013 and 2014.

After this preliminary survey, the most affected areas by the disease were identified, confirming nine in the urban area and four in the countryside, who counted on 13 ESF. It was also held the intersection of data between the number of cases per district and the number of IIP. Found that in 2014, the city has presented $1.64 \%$ of the IIP, which corresponds to the municipalities that are on alert, according to the rating of the Ministry of Health [9]. 
In this perspective, the impact of dengue control includes initially the earliest recognition of the epidemic and its alert. Besides the development of strategies, such as training of professionals, the establishment of intersectoral actions to control and prevent the disease that must count on the cooperation of the public sectors and society, such as education, urban cleaning, sanitation, among other representations that collaborate with the effective dengue control [10].

\section{Description of the development and the action plan activities}

Certain the areas and the Family Health Teams with the biggest number of infestations and confirmed cases, the places where there were workshops in the communities they were elected. It was necessary to make a timetable for previous schedule of activities, which enabled the implementation of the five crosssector workshops, performed in collaboration with representatives of the health service and other services involved 13 family health teams, epidemiological surveillance staff, health monitoring, endemic diseases, as well as representatives of the Environment Department, Public Hygiene Secretariat, the coordinator of social mobilization, community leaders, community members, schools and churches.

Because of the complexity of environmental factors that favor the proliferation of the Aedes aegypti, it is recommended that the municipality integrate and make partnerships, allowing to define effective actions to control dengue. Intersectoral management experience was also identified in a study conducted in Belo Horizonte, state of Minas Gerais, in Brazil, which strengthened the discussion, decision making and implementation of prevention and control measures [11].

In the present study, using intersectoral strategy, it was necessary to identify the knowledge of the agents about the disease, in addition to exposing the local epidemiological situation (indicators). Thus, lacking education, there were subsidized educational activities from conversation meetings. In the workshops, it was approached about dengue, showing its strength of reproduction, infestation and transmission capacity. Morever, presenting the disease in its clinical (signs and symptoms) and epidemiological factors seeking to inform the public about this social problem.

Study shows that the prior knowledge of popular conceptions is appropriate to recognize whether the severity of the disease and raise responsibility when promotes changes in community habits [12]. For even knowing the severity of the disease, people reveal their behavior/practice when throw garbage on the streets and in vacant lots, and store containers that hold water [13].

This makes clear the necessity to unite and mobilize the population in dengue control process, as effective results of sharing its space, which requires integrated actions, reformulated ideas and concepts for the development of educational activities and adoption of practices that causes the local control of the disease.

In the same study, epidemiological data of each location have been described, seeking to advice the subject about the importance of working the action plan and implement it in its context as a preventive measure for dengue vector control. The action plan was drafted by all involved, as model of a worksheet distributed at the workshops, which included the following guiding questions: What to do? When you do? Where to do? Who will do? and What will spend? This enabled the discussion of actions and individual and collective responsibilities. After these planned activities, actions have been implemented by all actors involved.

Planning and share of accountability involving public participation and intersectoral approach were strong links of the local action plan. It turns out that the development of the health plan covered important constituent parts, including the introduction and analysis of the health situation, has as objectives and proposals interventions. 
In this sense, by expanding the approach of dengue relating it as an urban socio-environmental problem, requires interventionist actions that seek to minimize the impact of the epidemic. Considering this premise, demand an efficient plan to combat, focusing on environmental issues and urbanized areas, consolidating effective actions in the areas with the highest incidence of the disease and complement the individual and collective actions to improve the quality of life in the community.

Due to the magnitude and severity of dengue requires the collaboration of various social agents and, according to one study, people's participation position represents a sensitivity index for the control of dengue, which emphasizes the health of municipal policy formulation [11]. This sharing of decisions and tasks on dengue directs efforts to achieve the goals that were agreed during the planning of actions, strengthening knowledge about the dynamics of infection.

\section{Contexts of dengue control actions}

In the present experiment, the relationship between the epidemiological and health surveillance was productive in terms of promoter informed actions in the action plan, so were developed the following actions in various community settings, such as active search for dengue mosquito focus on trades, cemeteries, schools and vacant lots, which had the support of Community Health Agents (CHA) and CAE (Community Agents of Endemic Diseases), who carried out each house to visit.

Study suggests that understanding about the complexity of the dengue problem requires action in the process of social determination, which is not restricted to the health sector, that's why it depends on ecosystem approach. This approach enables the participation and equity, since it includes local community and technicians to redirect the actions according to the peculiarities and specificities that the local context requires [6].
Concerning the public spaces, which in this study includes the unoccupied vacant lots, were carried out cleaning and weeding, followed by spraying site and surrounding areas. The intervention in these places is important because often serve for waste disposal by the population. So, they are considered strategic points to the proliferation of mosquitoes, especially in the rainy season.

Health actions in promoting campaign for prevention, cleaning and control of dengue are recurrent practice in many municipalities and considered effective strategy of dengue surveillance. Based on the epidemiological characteristics of each territory it has for purpose, raise awareness the population, identifying and mapping vacant lots and closed buildings, taking out the trash. In addition to identifying households with positive outbreaks, collaborating with the elimination of mosquito breeding sites [14].

During the surveillance work, it was instituted a 'D-Day' as a timely and preventive measure in vector control. The intention was to call the attention of the whole community and, therefore, there was prior contact with representatives of schools, churches and community at large, which attended the actions planned to consolidate this event.

In the occasion, students from local schools from the 1st to the 9th grade of elementary school and high school, crafted posters that caught those eyes as preventive care in dengue control. In the church, in general, the community participated in all mobilizing actions: hiking, guidelines, calls in general, calls faithful after Mass.

Also made available sound cars with municipal management support. Through this means of communication, information was provided with vignettes, which approached about the disease, transmission and prevention. This action was carried out in the neighborhoods with the highest number of dengue cases.

The reported experience confirms the global trend of creating dengue action plan services, win- 
ning support and confidence to create a favorable environment for the development of activities that include communication activities and social mobilization. These require the mobilization of several media and educational technologies that enable the transfer of information and collective action. These strategies are intended to raise awareness among individuals and have been important to enhance the information on dengue transmission [15].

All innovations in educational practices, communication and community mobilization identified in this experiment, were also identified in a study as innovations which have great relevance for the control of dengue, it opens opportunities for dialogue and conversation between different actors involved. However, they have little potential to produce or induce changes in behavior and attitudes. Still, it considers that the practice should be linked to strategies promoting health and intersectoral action, since the need to strengthen economic and legal disposable products, and the need of awakening professionals to review the principles that shape their practices in health.

\section{Specific actions for Health Team family}

Another important element of this action was the training of health professionals on the use of flow chart of all suspected cases and dengue notifications. The aim was to encourage the necessary technical capability and make them aware about the health surveillance of commitment in relation to dengue cases enrolled in your area.

The participation of the health team was part of a set of initiatives in addressing cases of dengue in the area, culminating in intervention, monitoring and social participation. Allowing health professionals consider feasible planning, the establishment of specific goals, choosing priorities, determining strategies and links with society, by implementing the inter-sectoral action and community participation.

In dengue control activities, education for health for each professional category is a challenge and at the same time, a path set. These enable the monitoring of routine actions, the proper approach to the cases and the adoption of a prevention model in which agents implementing it can forward the demands, which are related to other determinants, linking them to the intersectoral actions to protect the health of the community. [11] This continuing education in an interdisciplinary way enables integrated actions in the communities with the greatest performance of all actors involved, which enhances the dengue control measures.

\section{Potentialities and limitations of shares}

The execution of actions developed collectively and corresponsavelmente allowed to identify as potential, a decline in affected areas both in the number of reported and confirmed dengue cases, expressed by lower IIP. Were evidenced that the SE 25-32, 2014, there are 40 reported cases and of these, 13 confirmed cases and 27 discarded. From the SE 43, SE until the last of that year, 16 cases were reported and all discarded by laboratory serology.

It recognized the importance of local action in cities simultaneously involving social mobilization, the largest share of health surveillance, the realization of large joint effort that results in controlling the reproduction of the vector [17], as well as responsive service offering and effort in developing continuing education of health professionals and expansion of community knowledge. [11]

Whereas the importance of the community in actions involving health participation, particularly on the situation of dengue transmission in this experiment was in its infancy, though it may highlight that with knowledge, promote attitudes that lead to improved health and living conditions and their inclusion in health interventions.

Referring to the difficulties of inclusion and paricipação of the population in dengue control activities, they have also been identified in studies. But when has the community, consciously and actively, can reduce mosquito breeding sites and maintain healthy 
home environment and, therefore, has been touted as one of the main pillars of an effective control program Aedes aegypti [11].

One limitation of this study, it is emphasized that there was no involvement of higher education institutions. Study points to the importance of the participation of educational and research institutions that contribute to the technical and scientific knowledge multi and interdisciplinary, considering all areas of knowledge involved in the process. [4]

It is noteworthy, therefore, that intersectoral action make up the cast of situations that characterize the population to service delivery and the involvement of all stakeholders is unique condition for the full exercise of public health [18, 19].

Research should be implemented to give visibility to situations like these. However, although scientific production has been increasing in Brazil, significantly increase with the proper training of health professionals who work with research in project management [20].

This joint allows the co-responsibility, manages to imbue the problems of their community and becomes effective. However, we realize that actions such as these need to be strengthened, get into a routine of health services as part of the Continuing Education Policy, as Brazil is an endemic country and every year, waging struggles to prevent further outbreaks.

The importance which this activity was the inclusion of community participation in dengue control in selected districts, as encouraged involvement, enabled implementation of the action plan, essential to achieve the goal, which was the decrease in the number of cases with community support and other stakeholders as an effective way to respond with quality results to be pursued.

\section{Conclusion}

This experience has shown that actions to combat dengue become efficient in that it is able to develop joint actions, seeking inter-sectoral and community partnerships. Local initiative on dengue control has great value in the country, to make accessible this kind of attention and demonstrate their effectiveness to society.

\section{Conflict of interest}

The authors declare no conflict of interest.

\section{Acknowledgements}

This study was supported by Laboratory Design of Studies and Scientific Writing. ABC School of Medicine, Santo André , São Paulo, Brazil, and professor Luiz Carlos de Abreu for supported the study design, data collection and statistical analysis.

\section{References}

1. Boletim epidemiológico. Monitoramento dos casos de dengue e febre de chikungunya até a Semana Epidemiológica 15, 2015. Secretaria de Vigilância em Saúde - Ministério da Saúde. Brasil. 46(14). 2015. Disponível em: <http://portalsaude.saude.gov. br/images/pdf/2015/maio/04/2015-016---Boletim-DengueSE15-2015.pdf $>$. Acesso em: 15 junho 2015.

2. Ministério da Saúde (BR). Portal saúde: Dengue: LIRAa aponta 340 municípios em situação de risco. Disponível em: < htttp:// portalsaude.saude.gov.br/index.php/cidadao/principal/agenciasaude/17034-dengue-liraa-aponta-340-municipios-emsituacao-de-risco>. Acesso em: 15 de junho 2015.

3. Ceará. Informe Semanal Dengue 2015. Secretaria de Saúde. Governo do Estado do Ceará. 2015; 1-14. Disponível e: $<$ http://www.saude.ce.gov.br/index.php/boletins $>$. Acesso em 01 setembro 2015.

4. Mendonça FA, Souza AV, Dutra DA. Saúde Pública. Urbanização e Dengue no Brasil. Sociedade \& Natureza, Uberlândia. 2009; Dez, 21(3): 257-269.

5. Ferreira ITRN, Veras ASM, Silva RA. Participação da população no controle da dengue: u,a análise da sensibilidade dos planos de saúde de municípios do Estado de São Paulo, Brasil. Cad. Saúde Pública, Rio de Janeiro. 2009; Dez. 25(12): 26832694, dez,

6. Santos SL, Augusto LGS. Modelo multidimensional para o controle da dengue: uma proposta com base na reprodução social e situações de riscos. Physis Revista de Saúde Coletiva, Rio de Janeiro. 2011; 21(1): 177-196.

7. Ministério da Saúde (BR). Programa Nacional de Controle da Dengue (PNCD). Brasília. 2002; p.34. 
8. Ministério da Saúde. (BR). Organização e funcionamento do sistema de planejamento do SUS (Planeja SUS). Coordenação Geral de Planejamento, Subsecretaria de Planejamento e Orçamento, Secretaria Executiva, Ministério da Saúde. Brasília: Ministério da Saúde; 2006. (Série B - Textos Básicos de Saúde). p.52

9. Ministério da Saúde (BR). Levantamento Rápido de Índices para Aedes Aegypti (LIRAa) para vigilância entomológica do Aedes aegypti no Brasil: Métodologia para avaliação dos índices de Breteau e Predial e tipo de recipientes. Ministerio da Saúde, Secretaria de Vigilância em Saúde, Departamento de Vigilância das Doenças Transmissíveis - Brasília: Ministério da Saúde, 2013.

10. Teixeira TRA; Medronho RA. Indicadores sócio-demográficos e a epidemia de dengue em 2002 no Estado do Rio de Janeiro, Brasil. Cadernos de Saúde Pública, Rio de Janeiro. 2008; 24(9): 2160-170

11. Freitas RM; Rodrigues CS, Almeida MCM. Estratégia intersetorial para o controle da dengue em Belo Horizonte (Minas Gerais), Brasil. Saúde Soc. São Paulo. 2011; 20(3): 773-785.

12. Caregnato FF, Fetzer LO, Weber MA, Guerra TG. Educação ambiental como estratégoaia de prevenção à dengue no bairro do Arquipélago. Revista Brasileira de Biociências, Porto Alegre, RS. Brasil. 2008; Abr-Jun, 6(2): 131-136, 2008.

13. Gonçalves RC, Tavares ML, Faleiro JH, Rodrigues AS, Malafaia G. Dengue em Urataí, GO: conhecimentos, percepções da população e condições sanitária de suas residências. Arquivos Brasileiros de Ciências da Saúde. 2012; Jan-Abr, 37(1): 36-43.

14. Cavalcante MMB, Martins $P$, Albuquerque MV, Costa AA. Mutirões de combate à dengue: uma estratégia eficaz de controle da Infestação do Aedes aegypti. Sanare, Sobral,. 2010; Jan-Jun, 9(1): 23-26.

15. Barreto ML, Teixeira MG. Dengue no Brasil: situação epidemiológica e contribuições para uma agenda de pesquisa. Estudos Avançados. 2008; 22(64): 53-57.

16. Rangel-S ML. Dengue: educação, comunicação e mobilização na perspectiva do controle - propostas inovadoras. Interface (Botucatu) [online]. 2008; 12(25): 433-441.

17. Teixeira MG, Costa MCN, Barreto F, Barreto ML. Dengue: vinte e cinco anos da reemergência no Brasil. Cadernos de Saúde Pública, Rio de Janeiro,. 2009; 25(Supl. 1): 7-18.
18. Bezerra IMP, et al. Professional activity in the context of health education: a systematic review. Journal of Human Growth and Development, 24(3): 255-262

19. Atrash HK, Carpentier R. The evolving role of public health in the delivery of health care. Journal of Human Growth and Development, 2012; 22(3): 396-399.

20. Monteiro CBM, Almeida Junior AD, Wajnzstejn R. Project Management in Health and Medical Research. Journal of Human Growth and Development. 2014; 24(3): 239-242
Publish in International Archives of Medicine

International Archives of Medicine is an open access journal publishing articles encompassing all aspects of medical science and clinical practice. IAM is considered a megajournal with independent sections on all areas of medicine. IAM is a really international journal with authors and board members from all around the world. The journal is widely indexed and classified Q1 in category Medicine. 